\title{
Endophytic microbes from Nigerian ethnomedicinal plants: a potential source for bioactive secondary metabolites-a review
}

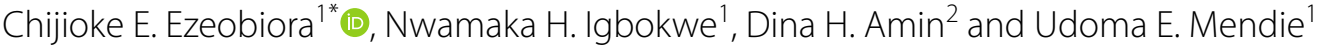

\begin{abstract}
Background: Endophytes are highly beneficial species of microbes that live in symbiosis with plant tissues in the setting. Endophytes are difficult to isolate in their natural environment, and they are understudied despite being a rich source of bioactive molecules. There are varieties of new infectious diseases emerging across the world, necessitating a constant and expanded search for newer and more efficient bioactive molecules. Nigeria is known for its biodiversity in ethnomedicinal plants, yet these plants are understudied for endophytic microbes harbouring novel bioactive molecules.

Main body: Endophytes are a source of novel organic natural molecules and are thought to be drug discovery frontiers. Endophyte research has contributed to the discovery of possible anticancer agents following the discovery of taxol. Endophyte research has contributed to the discovery of possible drug compounds with antimicrobial, antioxidant, antiviral, antidiabetic, anti-Alzheimers disease and immunosuppressive properties among others. These breakthroughs provide hope for combating incurable diseases, drug resistance, the emergence of new infectious diseases, and other human health issues. Finding new medicines that may be effective candidates for treating newly emerging diseases in humans has a lot of promise. Most studies have been on fungi endophytes, with just a few reports on bacterial endophytes. The biology of endophytic bacteria and fungi, as well as endophytic microbes isolated from Nigerian medicinal plants, their isolation methods, identification by morphological and molecular methods, fermentation, purification, identification of bioactive compounds and biosynthetic gene clusters are all covered in this study.

Conclusion: In Nigeria, the sourcing and isolation of endophytes harboring biosynthetic gene clusters are still understudied, necessitating a rigorous quest for bioactive molecules in endophytes inhabiting various ethnomedicinal plants.
\end{abstract}

Keywords: Endophytes, Medicinal plants, Isolation, Bioactive metabolites, Biosynthetic gene clusters

\section{Background}

Nigeria is rich in plant biodiversity, and these plants are home to millions of endophytic microbial species, which give the ability to discover a wide range of biologically significant compounds while also providing a sustainable source of natural products (Eze et al. 2018; Okoye

\footnotetext{
*Correspondence: chijiokeemmanuel177@yahoo.com

1 Department of Pharmaceutical Microbiology and Biotechnology,

Faculty of Pharmacy, University of Lagos, Lagos, Nigeria

Full list of author information is available at the end of the article
}

et al. 2015; Abba et al. 2016). According to the World Health Organization (WHO), infectious diseases continue to emerge and spread, and a lack of new antimicrobials jeopardizes global efforts to combat new and drug-resistant infections (2020). Hundreds of millions of recorded cases of covid-19, a recent pandemic that has afflicted the world and claimed the lives of 2.7 million people as recorded by the WHO (2021). This necessitates a massive quest for newer bioactive and antimicrobial compounds. Endophytic fungal populations of Nigerian medicinal plants have been studied and their enormous 
potential as sources of novel bioactive molecules has been highlighted, as well as the need to further explore Nigeria's plant biodiversity for endophytes producing biologically significant molecules (Ebada et al. 2016; Okezie et al. 2017; Akpotu et al. 2017). Plant-associated microorganisms called endophytes live in symbiosis with their host plants' living tissues. Many microorganisms, such as fungi, bacteria, and actinomycetes have been discovered in endophytic relationships with plants. Biosynthetic gene clusters (BGCs) have been found in these species. Endophytic fungi and bacteria live in plant tissue without causing disease symptoms, but they provide effective protection against phytopathogens (Gond et al. 2014). This allows them to generate a wide range of secondary metabolites, many of which have important biological activities and can be studied further for human health benefits. Secondary metabolites produced by endophytic association may be used to develop new compounds to combat the threats posed by multidrugresistant (MDR) and prodrug-resistant (PDR) microbial strains, as well as newer emerging disease conditions. Antimicrobial resistance is steadily increasing, prompting many antimicrobial experts to expect a return to the pre-antibiotic era (Blaskovich and Coope 2014, 2017). Endophytic fungi and actinobacteria have been established as sources of bioactive secondary metabolites that could be used to fight resistant microorganisms (El-sayed et al. 2019). Highly efficient, less harmful, and environmentally friendly chemicals must be produced, discovered, and investigated from natural or synthetic sources (Tenguria et al. 2018). Fungal endophytes are the most common form of plant endophyte, and they generate an enormous amount of secondary metabolites (Arnold and Engelbrecht 2007; Joseph and Mini 2011). Endophytes contain several chemical compounds, including saponin, alkaloids, benzophenones, phenolic acids, and others (Cragg and Newman 2013). Endophytes contain secondary compounds that are antiviral, anticancer, antidiabetic, and immunosuppressive in nature (Ali and Rante 2018). Seasonal, climatic, and political factors have caused some setbacks in traditional methods for extracting bioactive compounds from natural sources over the years. The environmental issues that researchers face during extraction necessitate novel approaches to obtaining these compounds. As a result, improved methods involving a variety of endophytic species can be cost-effective and provide a viable option for discovering a large and sustainable source of bioactive compounds (Madhusudhan et al. 2015). The large-scale processing of taxol (a valuable anticancer drug) from the bark of the yew plant used microbial fermentation. It addressed the issue of the yew plant's slow growth and endangered status (Zhou et al. 2010).
Endophytes of medicinal plants have recently gotten a lot of attention because they appear to contain natural products that are beneficial to humans (Gunatilaka 2006). Several of these medicinal plants have been tested for endophytes all over the world ( $\mathrm{Li}$ et al. 2008). Nigeria is not exempt in this respect. Several researchers in Nigeria have worked with a variety of native medicinal plants in pursuit of endophytes that could develop antimicrobial, anti-inflammatory, anticancer, antioxidative, and anti-leishmanicidal bioactive compounds.

The whole world is currently struggling with a variety of emerging infectious diseases. The latest covid-19 pandemic necessitates detailed research into effective antimicrobials. Several researchers are studying various infectious diseases to better understand and treat them using various natural and chemical formulations (Mane et al. 2017). Endophytes are one of those natural sources of bioactive agents. Researchers are attempting to isolate new bioactive compounds from newer species of endophytes for medicinal, agricultural, and industrial uses, despite their failure to clarify their origins, pathways, and mechanisms of action (Garg et al. 2011). It is therefore critical to encourage researchers to isolate novel bioactive compounds (Zuccaro et al. 2011).

Isolation, fermentation, extraction and structural elucidation are all steps in the process of discovering new bioactive compounds from endophytes. Scientists are interested in endophytic bioactive research because of the ecological, structural diversity and complexity of isolated compounds (Yuan et al. 2011). Crude natural products are mainly used in the pharmaceutical industry and are used to make semi-synthetic natural products (Suryanarayanan 2011; Mane et al. 2018). Pharmaceutical biotechnology includes the bioprospecting of fungal and bacterial endophytes for useful compounds. As a result, this analysis was performed to provide researchers with the knowledge they need to perform endophyte research.

\section{Main text \\ Biosynthetic potentials of endophytes}

Endophytes are currently used to make essential medicinal, chemical, and agricultural compounds that support humans. Endophytes contain high-value medicinal compounds such as taxol, podophyllotoxin, camptothecin, vinblastine, and vincristine, among others. As opposed to the traditional approach of using plants, which is nonabundant and uneconomical, endophytes as sources of bioactive compounds are less costly (Kumaran et al. 2010; Kumar et al. 2013). Endophyte-associated plants are known to develop metabolites that cause pathogen resistance. Also, secondary metabolites formed by these endophytes, such as antibiotics and lytic enzymes, provide defence against a variety of pathogens. Endophytes play 
an important role in pest and insect control in agriculture (Ahmed et al. 2012; Santos et al. 2003; Arnold et al. 2003). As compared to nonsymbiotic plants, plants associated with endophytes have been found to easily adapt and withstand abiotic stresses such as drought, salt, and heat (Gao et al. 2010; Jalgaonwala et al. 2011).

Endophytes are noted for developing a wide variety of biologically active natural products, which are classified as lignans, hormones, alkaloids, isocoumarins, terpenoids, phenylpropanoids, quinones, lactones, phenol and phenolic acids, aliphatic metabolites and so on. The study of secondary metabolites produced by endophytes of various host plants has become increasingly common around the world. Endophytes have developed several natural compounds with interesting biological properties such as antibiotics, antiviral, anticancer, antioxidants, insecticidal, antidiabetic, immunosuppressive properties and so on (Clay and Schardl 2011). It was also proposed that endophyte-derived antibiotic biomolecules could be used as a replacement for several chemically produced antibiotics which have recently been plagued by numerous drawbacks due to an increase in antimicrobial resistance (Waller et al. 2005; Madhusudhan et al. 2015; Padhi et al. 2013; Yu et al. 2010; Stinson et al. 2003; Strobel 2003). In Nigeria, there are few studies on the isolation of various bioactive compounds from endophytes. Table 1 shows few recent studies on isolated endophytes in Nigeria and their bioactive compounds.

\section{Endophytes as potential sources for curbing new emerging infectious diseases.}

Infections that have recently emerged, especially viral infections like Severe Acute Respiratory Syndrome (SARs-CoV or SARs) and Middle East Respiratory Syndrome (MERS-CoV or MERS), have caused regional and global outbreaks (Xu et al. 2020). At the end of 2019, a novel coronavirus, previously known as SARS-CoV-2, was reported as the cause of pneumonia in Wuhan, a city in China's Hubei Province. It has since spread to China and the rest of the world and it is now classified as a global health emergency (Xu et al. 2020).

Antiviral metabolites discovered and generated by endophytes have emerged as an exciting area in viral therapeutic and antiviral drug growth. Vaccines against $\mathrm{CoVs}$ are being produced all the time to reduce the prevalence of virally transmitted diseases. Natural bioactive compounds with potential as protease inhibitors and immunomodulators are abundant in endophytic microbes (Okoye et al. 2015). They have shown a lot of promise as possible candidates for antiviral drugs or alternative and complementary medicals for the prevention and treatment of CoVs (Suwannarach et al. 2020; Naik 2018).
Paclitaxel, an anticancer agent derived from endophytic fungi of the genera Alternaria, Aspergillus, Beauveria, Cladosporium, Chaetomella, Fusarium, Guignardia, Monochaetia, Nodulisporium, and Pestalotia, has been studied to possess the potential to treat CoVs (Naik 2018; Ryang et al. 2019). Many endophytic bioactive compounds have been investigated for their anti-coronavirus properties (2021). Endophytes were used to isolate antiCoVs compounds such as dimethyl asterriquinone D, ganolucidic acid A, ganoderic acid A, ganoderiol acid B, colossolactone A, E, G and V. These compounds have also been evaluated for anti-HIV and anti-cancer properties (Martinez-Montemayor et al. 2019; Dine et al. 2008).

\section{Culturing of endophytes \\ Selection of the plant material}

The medicinal plants used in endophyte studies are chosen after a thorough literature review using the internet, books and journals. Most endophyte researchers source endophytic bioactive molecules from plants or parts of plants based on ethnomedicinal information or application (Tsuchida et al. 2002).

\section{Collection of plant material}

The medicinal plants chosen for endophytic research are often found in natural ecosystems and botanical gardens. Plant sections that are free of disease are often collected with a sterile scalpel and stored in zip-lock plastic bags or polythene bags until isolation is completed within 48 hours (Tsuchida et al. 2002).

\section{Endophyte's isolation, purification and subculturing}

The first and most important step in isolating endophytes is surface sterilization. It is done to eliminate all epiphytes or surface microbes. Treatment of plant tissues with an oxidant or general sterilizing agent for a period, followed by $3-5$ times sterile rinse is the most common process (Tsuchida et al. 2002). Surface sterilization of plant tissue, aseptic cutting of sterilized sections into segments, plating the sterilized segments onto isolation media, usually Potato Dextrose Agar (PDA), Malt Extract Agar (MEA) for fungi and Nutrient Agar (NA), Luria Bertani (LB) Agar for bacteria, are the most used isolation procedures. Actinomycetes, which are filamentous bacteria that can be isolated as endophytes, are also cultured on Starch Casein Agar (SCA) and Brain-Heart Infusion (BHI) agar enriched thioglycolate broth. Macerated plant tissues may also be streaked onto the required agar media. The sterilizing agent can theoretically destroy any microbe on the plant surface without affecting the host tissue or endophytic microorganisms. Since the conditions needed to destroy the last microbe on the plant surface may already be lethal to certain endophytic microorganisms, 


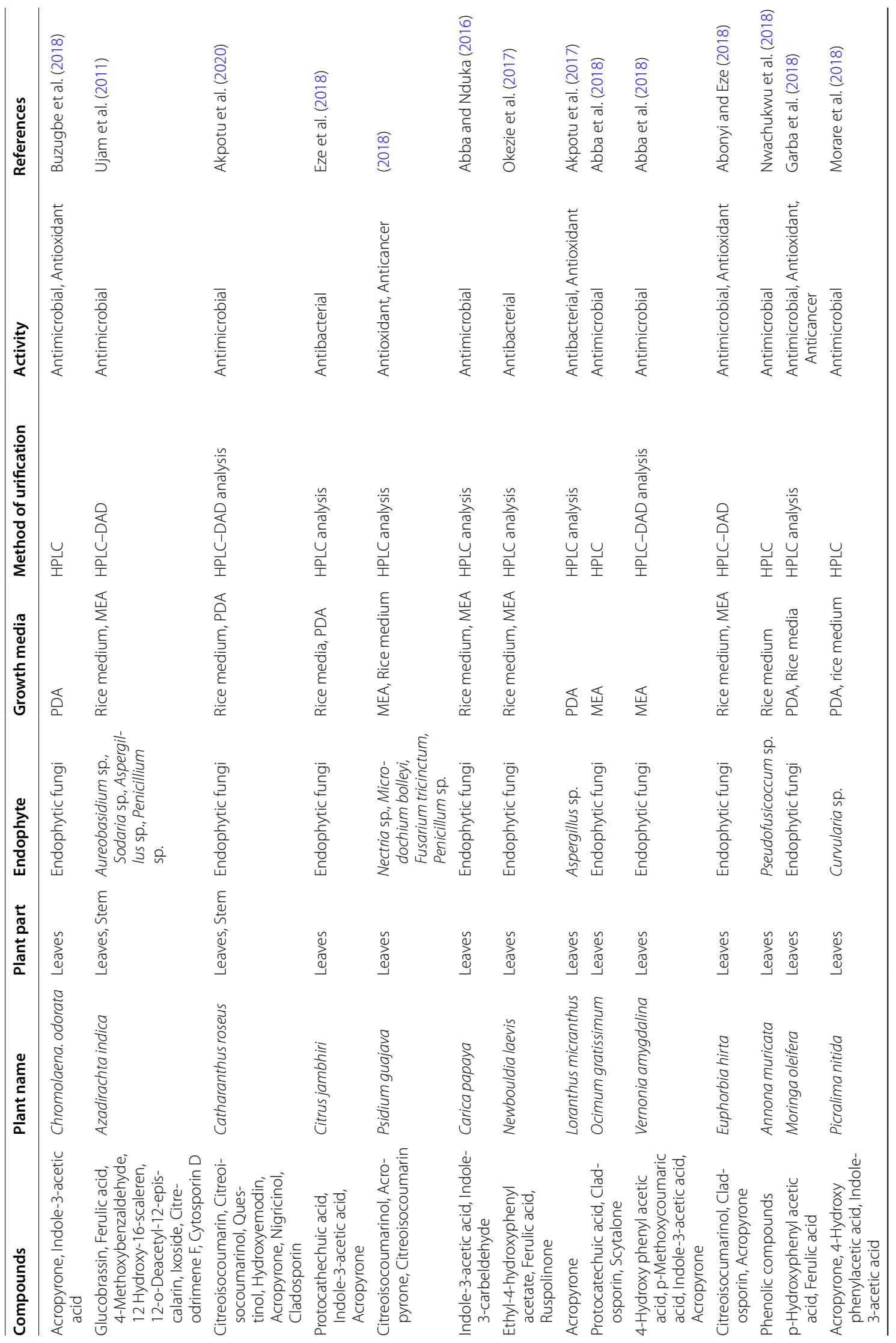




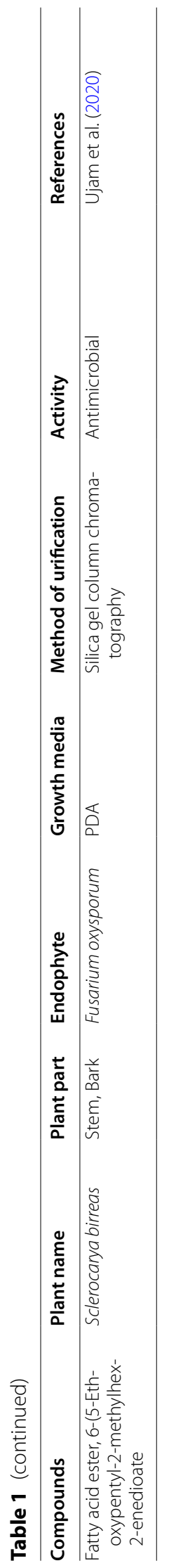


this is a difficult task. Furthermore, the sterilizing agent may penetrate plant tissue, killing endophytic microbes as a result. The following steps are involved in the isolation and purification of endophytic microbes from plant tissue:

1. Pre-treatment is the first step. It serves to remove adhering soil particles and most microbial surface epiphytes. It involves washing each plant's leaves, stems, and roots separately under the tap water (Tsuchida et al. 2002).

2. The second step involves the surface sterilization of the plant material. This entails soaking the freshly collected plant parts in slow running tap water for $15 \mathrm{~min}$, then washing them in Tween 20 ( 1 drop in $200 \mathrm{~mL}$ sterile distilled water [SDW]) for another minute and then rinsing them three times in SDW in the laminar airflow cabinet. Sodium hypochlorite (1-5 percent for 2-10 min), ethanol (70-95 percent for $30 \mathrm{~s}$ to $4 \mathrm{~min}$ ), hydrogen peroxide, and mercuric chloride (0.05-0.2 percent for $2-5 \mathrm{~min}$ ) are all commonly used sterilizing agents. Surface sterilization with 2 percent sodium hypochlorite, $70 \%$ ethanol, and 0.1 percent mercuric chloride is commonly used in most published research (Tsuchida et al. 2002).

Plant material will be cleaned and cut into small segments after being washed several times under running tap water. Following surface sterilization, the plant content is rinsed with 70 percent ethanol $\left(\mathrm{C}_{2} \mathrm{H}_{5} \mathrm{OH}\right)$ for $30 \mathrm{~s}$, 0.01 percent mercuric chloride $\left(\mathrm{HgCl}_{2}\right)$ for $5 \mathrm{~min}, 0.5$ percent sodium hypochlorite $(\mathrm{NaOCl})$ for $2-3 \mathrm{~min}$ and finally sterile distilled water for $2-3$ times. Before being placed in the isolation media, the plant material will be dried between the folds of sterile filter papers (Wright et al. 2012).

\section{Isolation of the endophytes}

After proper drying, endophytes are isolated from surface-sterilized plant materials. They are normally cut into smaller pieces to reveal the tissue before placing them aseptically onto the isolation media. Fungi are usually isolated using potato dextrose agar medium supplemented with chloramphenicol $(100 \mu \mathrm{g} / \mathrm{ml})$, while endophytic bacteria are isolated using nutrient agar or Luria Bertani agar supplemented with fluconazole $(30-50 \mu \mathrm{g} / \mathrm{ml})$ (Tsuchida et al. 2002; Wright et al. 2012). Plant materials such as stems, fruits, and roots are usually cut vertically into small segments to reveal the inner surface before being inoculated on the required media plates (Tsuchida et al. 2002; Wright et al. 2012). All the plates used to recover fungi endophytes are held at $28{ }^{\circ} \mathrm{C}$ for two to three weeks and are checked for microbial growth regularly. The bacterial recovery petri plates (with inoculated tissue samples) are incubated at $37{ }^{\circ} \mathrm{C} \pm 3{ }^{\circ} \mathrm{C}$ in the dark. Subculturing is achieved if microbial growth is detected. All endophytic cultures are purified before being moved to a freshly prepared media plate. Until incubation, parafilm tape is used to cover plates with plant tissues. For bacteria, the observations are normally made over $48 \mathrm{~h}$ while for fungi, they can take up to two weeks. Appropriate monitors in which no plant tissue is inoculated are also set up. The purified endophytic isolates are maintained by transferring onto appropriate agar slants at $4^{\circ} \mathrm{C}$ till further use (Tsuchida et al. 2002).

\section{Surface sterilization effectiveness test}

There are three approaches for assessing the efficacy of plant surface-sterilization. They are as follows:

1. Using surface-sterilized plant tissue to imprint onto nutrient media.

2. Dipping the treated explants into the nutrient broth.

3. Culturing aliquots of water from the last rinsing onto nutrient media.

After incubation, no microbial growth should be visible on the medium if the test was carried out properly. Surface sterilization is considered complete in this situation and isolated microbes from the plant parts thereafter are known as endophytes. The isolated microorganisms can only be classified as endophytes after full surface sterilization of the plant tissue is verified.

\section{Endophytes' isolation media}

The type of growth medium used has a direct effect on the amount and type of endophytic microorganisms isolated. Endophytic bacteria and fungi are isolated using nutrient agar (NA) and potato dextrose media respectively. Since nutrient agar contains no component that inhibits the growth of endophytic fungi, the media used to isolate endophytic bacteria are supplemented with an antifungal agent, such as nystatin or fluconazole, at a concentration of 30-50 $\mu \mathrm{g} / \mathrm{mL}$ of each (Tsuchida et al. 2002). Endophytic fungi are isolated using potato dextrose agar (PDA) supplemented with $100 \mu \mathrm{g} / \mathrm{ml}$ chloramphenicol. It is fortified with chloramphenicol to suppress the growth of bacteria.

\section{Endophyte characterization Endophyte morphological characterization (preliminary)}

All the bacteria isolates' phenotypic characteristics, such as microscopic features, gram reaction, endospore staining, motility, catalase and oxidase activity are determined using standard procedures. Culture features, spore formations and mycelium are used to classify endophytic 
fungi. Tease mount slides using Lactophenol Cotton Blue reagent are usually prepared and observed at 40X and 100X magnifications (Wright et al. 2012).

\section{Endophyte molecular identification}

\section{i. Genomic DNA extraction}

Each endophytic isolate's genomic DNA is extracted from pure colonies using a fungal/bacterial DNA extraction kit that is controlled according to the manufacturer's instructions (Wright et al. 2012). The internal transcribed spacer (ITS) region of the extracted DNA is then amplified using polymerase chain reaction (PCR) using primers with specific base sequences under the following conditions: Initial denaturation at $90{ }^{\circ} \mathrm{C}$ for $15 \mathrm{~min}$; denaturation at $95^{\circ} \mathrm{C}$ for $1 \mathrm{~min}$; annealing at $56^{\circ} \mathrm{C}$ for $1 \mathrm{~min}$ ute (Hu et al. 2012).

ii. Polymerase chain reaction (PCR) of the rRNA genes and sequencing experiments.

Polymerase chain reaction (PCR) and subsequent DNA sequencing are used in most new endophyte identification methods. Amplification of the Internal Transcribe Spacer (ITS) region, which is a repeating unit of DNA that encodes ribosomal RNA, is the best way to identify fungal endophytes while $16 \mathrm{~S}$ rRNA sequencing is used for bacteria identification. If the amplified DNA is sequenced and compared to a database, it can be used to decide if the specimen is novel; if the sequence is recognized, the species can be identified (Tidke et al. 2017). The primers (16S-27F: 5'-AGAGTTTGATCMTGGCTCAG-3' and 16S-1492R: 5'- CGGTTACCTTGTTACGACTT-3') can be used to amplify the 16S rRNA gene of each bacteria endophyte. The internal transcribed spacer (ITS) region of the extracted DNA is also amplified using the primers ITS1 (with base sequences 5'-TCCGTAGGTGAACCT GCGG-3') and ITS4 (with base sequences 5'TCCTCC GCTTATTGATATGC-3') under the required conditions on the extracted fungi DNA. The base sequences of the PCR products are compared to the data in Gene bank (Hu et al. 2012; Amin et al. 2020).

\section{Phylogenetic analysis}

The gene sequences (base pairs) are screened for chimeras using DECIPHER, then Basic Local Alignment Search Tool (BLAST) is used to find closely related endophytic bacterial or fungal species (Amin et al. 2020), typically at the National Center for Biotech Information (NCBI). Using Multiple Sequence Comparison by Log Expectation (MUSCLE), highly related sequences with 96 to 100 percent identity are compared with endophyte sequences isolated. The Neighbour-Joining approach is often used to draw phylogenetic trees. Molecular Evolutionary
Genetics Analysis (MEGA) is used to conduct evolutionary analysis. All endophyte sequences are deposited in GenBank with accession numbers (Amin et al. 2019).

\section{Secondary metabolites' production by endophytes}

Endophytes from bacteria and fungi are cultured separately in $1 \mathrm{~L}$ Erlenmeyer flasks containing $500 \mathrm{~mL}$ of sterile nutrient broth media and $500 \mathrm{~mL}$ of potato dextrose broth media for metabolite development. The media should be shaken for 7 days at $200 \mathrm{rpm}$ and $30{ }^{\circ} \mathrm{C}$. Most isolated endophytic fungi are fermented in a $1 \mathrm{~L}$ Erlenmeyer flask containing sterilized rice medium (prepared by autoclaving a mixture of $100 \mathrm{~g}$ rice and $100 \mathrm{ml}$ distilled water) (Hu et al. 2012). The flasks are inoculated with pure culture agar blocks $3 \mathrm{~mm}$ in diameter and incubated for 21 days at $25-27{ }^{\circ} \mathrm{C}$. The secondary metabolites are extracted with appropriate solvent e.g., ethyl acetate after the fermentation is finished and then concentrated under vacuum at $40{ }^{\circ} \mathrm{C}$. The crude extract is obtained by drying the solvent-soluble fractions using a rotary evaporator (Hu et al. 2012). Endophytic fungi and bacteria crude extracts are now used to monitor for bioactivity.

\section{Purification of bioactive compounds extracted from endophytes}

In endophytic biomolecule research, this is a critical step. After the endophytes have been successfully cultured, the fractions extracted from the growth media will be subjected to bioassays to validate the endophyte's suitability for isolating the required active compounds.

The most commonly used approach is liquid-liquid extraction, which involves injecting an organic solvent into the liquid media of an endophyte culture (Hu et al. 2012). For extraction, several solvents may be used alone or in combination, depending on the solubility of the desired metabolite. The most used solvents for extracting metabolites from culture broth are ethyl acetate, methanol, dichloromethane, acetone, hexane, and ethanol ( $\mathrm{Hu}$ et al. 2012) which are then dried by flash evaporation. If further purification is needed, the obtained fractions will be subjected to chromatographic techniques such as TLC and HPLC. Finally, gas chromatography (GC), nuclear magnetic resonance (NMR) or mass spectrometry (MS) can be used to validate the recovered fraction.

The two most popular techniques for determining structure are NMR and MS. X-ray diffraction (XRD) is also being considered as a method for crystallizing biomolecule (Hu et al. 2012).

\section{Screening for natural product biosynthetic gene clusters} When looking for biosynthetic gene clusters, the polymerase chain reaction (PCR) approach is commonly used. Polyketide synthase I (PKS-1), polyketide synthase 
II (PKS-II), and non-ribosomal peptide synthetase (NRPS) are the three main target genes (Hu et al. 2012; Tidke et al. 2017; Amin et al. 2019). For PCR amplification, three sets of degenerate primers targeting biosynthetic genes are usually used: KSF (50-GTSCCSGTSSCRTGSSHYTCSA-30) and KSR (50-CGCTCCATG GAYCCSCARCA-30), which target polyketide synthase (PKS)-I KS and methyl malonyl transferase domains; KSaF (50-TSGCSTGCTTGGAYGCSATC-30) and KSaR (50-TGGAANCCGCCGAABCCGCT-30), targeting PKS-II KSa genes and A3F (50-GCSTACSYSATSTACACSTCSGG-30) and A7R (50-SASGTCVCCSGTSCGGTAS-30), targeting non-ribosomal peptide synthetase (NRPS) genes. The amplified PCR products are analyzed by electrophoresis on $1 \%$ agarose gels. A negative control without a DNA template is often included with each PCR (Kun et al. 2010).

\section{Future perspectives}

The ability to use endophytes to produce useful biomolecules as an effective and long-term alternative to traditional methods of searching for these biomolecules opens the possibility of using them as an effective and long-term alternative to traditional methods of searching for these biomolecules. Industrial development of these valuable compounds through endophytes, on the other hand, is still a long way off. The quest for bioactive molecules in endophytes isolated from Nigerian ethnomedicinal plants have not been thoroughly investigated. Furthermore, the majority of previous research has focused on endophytic fungi. In the endophytic bacteria and actinomycetes' study, there is still a large gap that needs to be filled. There is a decrease in biomolecule generation with successive subculturing under certain condition. This has greatly hampered industrial applications of endophytes. Because of the significant endophytic contact with the host plant, even slight changes in culture conditions can have a significant impact on secondary metabolite output. Identification of improved strains suitable for fermentation from natural sources, genetic modification of existing strains to boost productivity using biotechnological procedures and optimization of culture conditions for increased yields are all necessary. As a result, a thorough investigation is needed to comprehend the interactions that are suitable for the large-scale development of bioactive molecules through endophytes. Whole-genome sequencing studies of isolated endophytic microbes are also needed.

\section{Conclusion}

Endophytes as a drug source can aid in the conservation of biodiversity and antimicrobial resistance since they are non-traditional drug sources. Endophytes may be able to replace conventional drug development approaches. Endophytes hold promise as a source of bioactive compounds with potential for human benefit. The sourcing and isolation of endophytes containing biosynthetic gene clusters are still understudied in Nigeria, so a thorough search for bioactive molecules from endophytes inhabiting various Nigerian ethnomedicinal plants is needed.

\begin{abstract}
Abbreviations
PDA: Potato dextrose agar; LB: Luria Bertani; HPLC: High performance liquid chromatography; HPLC-DAD: High performance liquid chromatography with diode array detection; MEA: Malt extract agar; BGCs: Biosynthetic gene clusters; CoVs: Coronaviruses; SARs: Severe acute respiratory syndrome; HIV: Human immunodeficiency virus; MERS: Middle East respiratory syndrome; SCA: Starch casein agar; BHI: Brain heart infusion; NA: Nutrient agar; MDR: Multidrug resistant; PDR: Prodrug resistant; DNA: Deoxyribonucleic acid; PCR Polymerase chain reaction; ITS: Internal transcribed spacer; RNA: Ribonucleic acid; rRNA: Ribose ribonucleic acid; BLAST: Basic local alignment search tool; NCBI: National Center for Biotech Information; MUSCLE: Multiple sequence comparison by log expectation; MEGA: Molecular evolutionary genetic analysis; TLC: Thin layer chromatography; GC: Gas chromatography; NMR: Nuclear magnetic resonance; MS: Mass spectrometry; XRD: X-ray diffraction; PKS-I: Polyketide synthase I; PKS-II: Polyketide synthase II; NRPS: Non-ribosomal peptide synthetase; WHO: World Health Organisation.
\end{abstract}

\section{Acknowledgements}

Not applicable.

\section{Authors' contributions}

ECE conceived the project and was a major contributor in writing the manuscript; INH, DHA and MUE supervised the project. All authors read and approved the final manuscript.

\section{Funding}

There was no special funding for the research. The authors funded the research.

\section{Availability of data and materials}

Not applicable.

\section{Declarations}

Ethics approval and consent to participate

Not applicable.

\section{Consent for publication}

Not applicable.

\section{Competing interests}

The authors declare that they have no competing interests.

\section{Author details}

'Department of Pharmaceutical Microbiology and Biotechnology, Faculty of Pharmacy, University of Lagos, Lagos, Nigeria. ${ }^{2}$ Department of Microbiology, Faculty of Science, Ain Shams University, Cairo, Egypt.

Received: 8 April 2021 Accepted: 31 May 2021

Published online: 08 June 2021

\section{References}

Abba CC, Nduka I (2016) Antimicrobial activity of secondary metabolites of endophytic Aspergillus species isolated from Loranthus micranthus. Afr J Pharma Res Dev 8(2):136-140 
Abba CC, Nduka I, Eze PM, Ujam TN, Abonyi DO, Okoye FBC (2016) Antimicrobial activity of secondary metabolites of endophytic Aspergillus Species Isolated from Loranthus micranthus. Afr J Pharma Res Dev 8(2):136-140

Abba CC, Eze PM, Abonyi DO, Nwachukwu CU, Proksch P, Okoye FBC, Eboka CJ (2018) Phenolic compounds from endophytic Pseudofusicoccum sp. isolated from Annona muricata. Trop J Nat Prod Res 2(7):332-337

Abonyi DO, Eze PM (2018) Biologically active phenolic acids produced by Aspergillus sp. an endophyte of Moringa oleifera. Euro J Biol Res 8(3):158-168

Ahmed M, Hussain M, Dhar M (2012) Sanjana K (2012) Isolation of microbial endophytes from some ethnomedicinal plants of Jammu and Kashmir. J Nat Prod Plant Resour 2(2):215-220

Akpotu MO, Eze PM, Abba CC, Umeokoli BO, Nwachukwu CU, Okoye FBC, Esimone CO (2017) Antimicrobial activities of secondary metabolites of endophytic fungi isolated from Catharanthus roseus. J Health Sci 7(1):15-22

Akpotu MO, Eze PM, Abba CC, Nwachukwu CU, Okoye FBC, Esimone CO (2017) Metabolites of endophytic fungi isolated from Euphorbia hirta growing in southern Nigeria. Chem Sci Rev Lett 6(21):12-19

Akpotu O, Eze PM, Abba PC, Nwachukwu C, Okoye BC, Esimone C (2020) Antimicrobial Activities of secondary metabolites of endophytic fungi isolated from Catharanthus roseus. J Health Sci 7(1):15-22

Ali A, Rante H (2018) Screening of endophytic bacteria producing antifungal isolated from Indonesia medicinal plant, Talinum triangulare. Int J Pharm Pharm Sci 10(6):152-158

Amin HD, Abolmatty A, Borsetto C, Tolba S, Abdallah AN, Wellington ME (2019) In silico genomic mining reveals unexplored bioactive potential of rare actinobacteria isolated from Egyptian soil. Bull Natl Res Cent 43(78):1-9

Amin HD, Abdallah AN, Abolmaaty A, Tolba S, Wellington ME (2020) Microbiological and molecular insights on rare actinobacteria harbouring bioactive prospective. Bull Natl Res Cent 44(5):1-12

Arnold AE, Engelbrecht BMJ (2007) Fungal endophytes nearly double minimum leaf conductance in seedlings of a neotropical tree species. J Trop Ecol 23(3):369

Arnold AE, Mejia LC, Kyllo D, Rojas El, Zuleyka M, Nancy R, Edward AH (2003) Fungal endophytes limit pathogen damage in a tropical tree. Proc Natl Acad Sci 100(26):15649-15654

Blaskovich MAT, Coope MA (2017) Antibiotics in the clinical pipeline at the end of 2015. J Antibiot 70:3-24

Buzugbe HS, Eze PM, Chukwunwe Jim CR, Nwachukwu CU, Abonyi DO, Abba CC, Okoye FBC, Esimone CO (2018) Investigation of secondary metabolites of an endophytic fungus isolated from the leaves of Chromolaena odorata for possible antimicrobial and antioxidant Activities. Pharm Chem J 5(6):72-77

Clay K, Schardl CL (2011) Evolutionary origin and ecological consequences of endophyte symbiosis with grasses. Am Nat 160:S99-S127

Cragg GM, Newman DJ (2013) Natural products: a continuing source of novel drug leads. Biochim Biophys Acta 1830(6):3670-3695

Ebada SS, Eze P, Okoye FBC, Esimone CO, Proksch P (2016) The fungal endophyte Nigrospora oryzae produces quercetin monoglycosides previously known only from plants. Chem Select 1:2767-2771

El Dine RS, Halawany AM, Ma CM, Hattori M (2008) Anti-HIV1- protease activity of lanostane triterpenes from the Vienamese mushroom Ganoderma colossum. J Nat Prod 71:1022-1026

El-sayed AS, Mohamed NZ, Safan S, Yassin MA, Shaban L, Shindia AA, Shad A, Sitohy MZ (2019) Restoring the taxol biosynthetic machinery of Aspergillus terreus by Podocarpus gracilior pilger microbiome, with retrieving the ribosome biogenesis proteins of $\mathrm{WD}_{40}$ super family. Sci Rep 9:9-25

Emmanuel E, Eze PM, Ogwaluonye UC, Ilo ES, Nwankwo OL, Okoye FBC, Esimone CO (2018) Antimicrobial, antioxidant and cytotoxic properties of secondary metabolites from endophytic fungi of Psidium guajava. Pharm Chem J 5(6):72-77. 2019; 6(1):90-97

Eze PM, Ojimba NK, Abonyi DO, Chukwunwejim CR, Abba CC, Okoye FBC, Esimone CO (2018) Antimicrobial activity of metabolites of an endophytic fungus isolated from the leaves of Citrus jambhiri (Rutaceae). Trop J Nat Prod Res 2(3):145-149

Eze PM, Ojimba NK, Abonyi DO, Chukwunwejim CR, Abba CC, Okoye FBC, Esimone CO (2018) Antimicrobial activity of metabolites of an endophytic fungus isolated from the leaves of Citrus jambhiri. Trop J Nat Prod Res 2(3):145-149
Gao F, Dai C, Liu X (2010) Mechanisms of fungal endophytes inplant protection against pathogens. Afr J Microbiol Res 4(13):1346-1351

Garba SA, Mudi SY, Muhammed AH, Abdullahi S (2018) Assessment of bioactive compounds produced by endophytic fungus isolated from Sclerocarya birrea Plant. NRJCS 4:123-133

Garg N, Meena A, Nain J (2011) Evaluation of physicochemical and preliminary phytochemical studies on the root of Bombax ceiba Linn. Int J Pharm Sci Res 2:924-926

Gond SK, Kharwar RN, White JF (2014) Will fungi be the new source of the blockbuster drug taxol? Fungal Biol Rev 28:77-84

Gunatilaka AL (2006) Natural products from plant-associated microorganism: distribution, structural diversity, bioactivity and implications of their occurrence. J Nat Prod 69:509-526

Hu Y, Martinez ED, MacMillan JB (2012) Anthraquinones from a marine-Derived Streptomyces Spinoverrucosus. J Nat Prod 75:1759-1764

Jalgaonwala RE, Mohite BV, Mahajan RT (2011) A review: natural products from plant associated endophytic fungi. J Microbiol Biotech Res 1(2):21-32

Joseph B, Mini PR (2011) Bioactive compounds from endophytes and their potential in pharmaceutical effect: a review. Am J Biochem Mol Biol 1(3):291-309

Kumar A, Patil D, Rajamohanan PR, Ahmad A (2013) Isolation, purification and characterization of vinblastine and vincristine from endophytic fungus Fusarium oxysporum isolated from Catharanthus roseus. PLOS ONE $8(9): 1-10$

Kumaran RS, Kim HJ, Hur B (2010) Taxol promising fungal endophyte Pestalotiopsis species isolated from Taxus cuspidate. J Biosci Bioeng 110(5):541-546

Kun L, Zhixiang Z, Xiaofei L (2010) Screening for PKS genes from soil metagenomics library and identification of actives against root-knot nematodes. Plant Prot 36:38-42

Li J, Zhao GZ, Chen HH, Wang HB, Qin S, Zhu WY, Xu LH, Jiang CL, Li WJ (2008) Antitumour and antimicrobial activities of endophytic streptomycetes from pharmaceutical plants in rainforest. Lett Appl Microbiol 47:574-580

Madhusudhan MC, Bharathi TR, Prakash HS (2015) Isolation and purification of bioactive metabolites from fungal endophytes - a review. Curr Eng J 2:111-117

Madhusudhan MC, Bharathi TR, Prakash HS (2015) Isolation and purification of bioactive metabolites from fungal endophytes-a review. Curr Biochem Eng 2:111-117

Mane R, Shinde M, Wagh P, Malkar H (2017) Isolation of endophytic microorganisms as a source of novel secondary metabolite producers against tuberculosis. IJSTR 3:1267-1269

Mane RS, Paarakh PM, Vedamurthy AB (2018) Brief review on fungal endophytes. IJSM 5(4):288-303

Martinez-Montemayor M, Ling T, Suárez-Arroyo J, Ortiz-Soto G, SantiagoNegrón CL, Lacourt-Ventura MY, Valentín-Acevedo A, Lang WH, Rivas F (2019) Identification of biologically active Ganoderma lucidum compounds and synthesis of improved derivatives that confer anti-cancer activities in vitro. Front Pharmacol 10:115

Morare FR, Ubomba-Jaswa E, Serepa-Dlamini MH (2018) Isolation and identification of bacterial endophytes from Crinum macowanii. Afr J Biotechnol 17(33):1040-1047

Naik BS (2018) Developments in taxol production through endophytic fungal biotechnology: a review. Orient Pharm Exp Med 19:1-13

Nwachukwu CU, Ngwoke KG, Eze PM, Eboka CJ, Okoye FBC (2018) Secondary metabolite from Curvularia sp., an endophytic fungus isolated from the leaves of Picralima nitida (Apocyanaceae). Trop J Nat Prod Res 2(5):209-213

Okezie UM, Eze PM, Okoye FBC, lkegbunam MN, Ugwu MC, Esimone CO (2017) Biologically active metabolites of endophytic fungus isolated from Vernonia amygdalina. Afr J Pharm Res Dev 9(1):24-29

Okezie UM, Eze PM, Okoye FBC, Ikegbunam MN, Ugwu MC, Esimone CO (2017) Biologically active metabolites of an endophytic fungus isolated from Vernonia amygdalina. Afr J Pharm Res Dev 9(1):24-29

Okoye FBC, Nworu CS, Debbab A, Esimone CO, Proksch P (2015) Two new cytochalasins from an endophytic fungus, KL-1.1 isolated from Psidium guajava leaves. Phytochem Lett 14:51-55

Padhi L, Mohanta YK, Panda SK (2013) Endophytic fungi with great promises: a review. J Adv Pharm Educ Res 3(3):152-171 
Ryang J, Yan Y, Song Y, Liu F, Ng TB (2019) Anti-HIV, antitumor and immunomodulatory activities of paclitaxel from fermentation broth using molecular imprinting technique. AMB Express 9:1-10

Santos RM, Rodrigues-Fo E, Roch WC, Teixeira MF (2003) Endophytic fungi from Melia azedarach. World J Microbial Biotech 19:767-770

Stinson M, Ezra D, Strobel G (2003) An endophytic Gliocladium sp. of Eucryphia cordifolia producing selective volatile antimicrobial compounds. Plant Sci 165:913-922

Strobel GA (2003) Endophytes as sources of bioactive products. Microb Infect 5:535-544

Suryanarayanan S (2011) Diversity of fungal endophytes in tropical trees. J for Sci 80:67-80

Suwannarach N, Kumla J, Sujarit K, Pattananandecha T, Saenjum C, Lumyong S (2020) Natural bioactive compounds from fungi as potential candidates for protease inhibitors and immunomodulators to Apply for corona viruses. Molecules 25(8):1800

Tenguria R, Kumar KFN, Quereshi S (2018) Endophytes-mines of pharmacological therapeutics. World J Sci Technol 1(15):127-149

Tidke AS, Rakesh KK, Ramakrishna D, Kiran S, Kosturkova G, Gokare AR (2017) Current understanding of endophytes: their relevance, importance and industrial potentials. IOSR J Biotechnol Biochem 3(3):43-49

Tsuchida T, Koga R, Shobao H, Matsumoto T, Fukatsu T (2002) Diversity and geographic distribution of secondary endosymbiotic bacteria in natural populations of the pea aphid Acyrthosiphon pisum. Mol Ecol 11:2123-2135

Ujam NT, Abba CC, Eze PM, Oli AN, Ejikeugwu CE, Ugwu MC, Okoye FBC, Esimone CO (2011) The isolation, identification and antimicrobial activities of endophytic fungi from Azadirachta indica. GSC Biol Pharmaceut Sci 11(3):115-124

Ujam NT, Abba CC, Eze PM, Oli AN, Ejikeugwu CE, Ugwu MC, Okoye FBC, Esimone CO (2020) The isolation, identification and antimicrobial activities of endophytic fungi from Azadirachta indica. GSC Biol Pharmaceut Sci 11(3):115-124

Waller F, Aehatz B, Baltruschat HJ, Becker K, Fischer M, Heier T, Huckelhoven R, Neumann C, Wettstein DV, Franken P, Kogel K (2005) The endophytic fungus Piriformospora indica reprograms barley to salt stress tolerance, disease resistance, and higher yield. Proc Natl Acad Sci 102(38):13386-13391

World Health Organization (2014) Antimicrobial resistance: global report on surveillance

World Health Organization (2020) Lack of new antibiotics threatens global efforts to contain drug resistant infections. New release Geneva

World Health Organization (2021) WHO Health Emergency Dashboard. WHO (Covid-19) Home page

Wright ES, Yilmaz LS, Noguera DR (2012) DECIPHER, a search-based approach to chimera identification for $16 \mathrm{~S}$ rRNA sequences. Appl Environ Microbio 78(3):717-725

Xu J, Zhao S, Teng T, Abdalla AE, Zhu W, Xie L, Wang Y, Guo X (2020) Systematic comparison of two animal-to-human transmitted human corona viruses: SARS-CoV-2 and SARS-CoV. Viruses 12:244

Yu H, Zhang L, Li L, Zheng C, Guo L, Li W, Sun P, Qin L (2010) Recent developments and future prospects of antimicrobial metabolites produced by endophytes. Microbiol Res 165:437-449

Yuan Z, Su Z, Mao L, Peng Y, Yang G, Lin F, Zhang C (2011) Distinctive endophytic fungal assemblage in stems of wild rice (Oryza granulata) in China with special reference to two species of Muscodor (xylariaceae). J Microbiol 49:15-23

Zhou X, Zhu H, Liu L, Lin J, Tang K (2010) A review: recent advances and future prospects of taxol-producing endophytic fungi. Appl Microbiol Biotechnol 86:1707-1717

Zuccaro A, Lahrmann U, Guldener U, Langen G, Pfiffi S, Biedenkopf D, Wong P, Samans B, Grimm C, Basiewicz M, Murat C, Martin F, Kogel K (2011) Endophytic life strategies decoded by genome and transcriptome analyses of the mutualistic root symbiont Piriformospora indica. PLoS Pathog 7:123-129

\section{Publisher's Note}

Springer Nature remains neutral with regard to jurisdictional claims in published maps and institutional affiliations.

\section{Submit your manuscript to a SpringerOpen ${ }^{\circ}$ journal and benefit from:}

- Convenient online submission

- Rigorous peer review

- Open access: articles freely available online

- High visibility within the field

- Retaining the copyright to your article

Submit your next manuscript at springeropen.com 